\title{
Mursi ox modification in the Lower Omo Valley and the interpretation of cattle rock art in Ethiopia
}

Timothy Insoll ${ }^{1 *}$, Timothy Clack $^{2} \&$ Olirege Rege $^{3}$

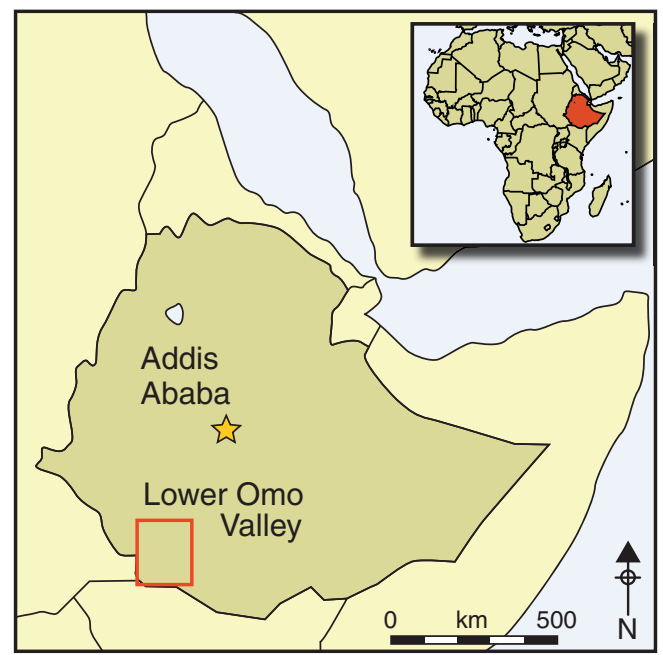

Cattle are a key focus of traditional pastoralist societies in eastern Africa and also figure prominently in the rock art of the region. In both contexts, their cultural and social significance is underscored by colour and decoration. The contemporary Mursi of southwest Ethiopia transform favourite oxen in various ways, including horn alteration, ear cutting and decorative pattern branding. These practices may provide direct insight into cattle portrayal in Ethiopian rock art, where abstract or non-realistic symbols depicted on cattle coats could indicate the modification, alteration or beautification of cattle in prehistoric societies.

Keywords: Lower Omo Valley, Mursi, cattle pastoralism, pattern branding, horn shaping, rock art

\section{Introduction}

As an adjunct to ongoing archaeological research focusing on the Dirikoro area of Mursi territory in the far south-west of Ethiopia (cf. Clack \& Brittain 2011a \& b), data were collected in March-April 2013 on how cattle are modified, particularly with regard to decorative pattern branding. Cattle colour patterns have been the focus of research amongst the Mursi (Turton 1980) and neighbouring groups such as the Nyangatom, Dassanetch and Bodi (Almagor 1972; Tornay 1973; Fukui 1996), and, along with horn modification, more widely in northern Kenya and South Sudan (e.g. Evans-Pritchard 1940, 1956; Lienhardt 1961; Hazel 1997). The much less common practice of deliberately branding decorative patterns onto cattle, however, appears to have been neglected except for brief mention of it

1 Department of Archaeology, University of Manchester, Mansfield Cooper Building, Oxford Road, Manchester M139PL, UK (Email: Tim.Insoll@manchester.ac.uk)

African Studies Centre, University of Oxford, 13 Bevington Road, Oxford OX2 6LH, UK

Independent researcher, Mursiland, Ethiopia

Author for correspondence 
amongst the Hamar, also of south-west Ethiopia (Dubosson 2013: 83). This is an omission, as it may be relevant for interpreting cattle imagery in rock paintings and engravings in Ethiopia where bovine representation is common.

\section{Mursi-archaeological and historical context}

The Mursi number about 10000 , are agro-pastoralists and occupy an area centred on the Mursi Mountains, the adjacent plain to the west referred to dramatically by the Italians as 'The Plain of Death' (Bolton 1976: 135), and part of the Mago Valley (Figure 1). They speak a Surmic language within the East-Sudanic division of the Nilo-Saharan family (Turton et al. 2008: 7).

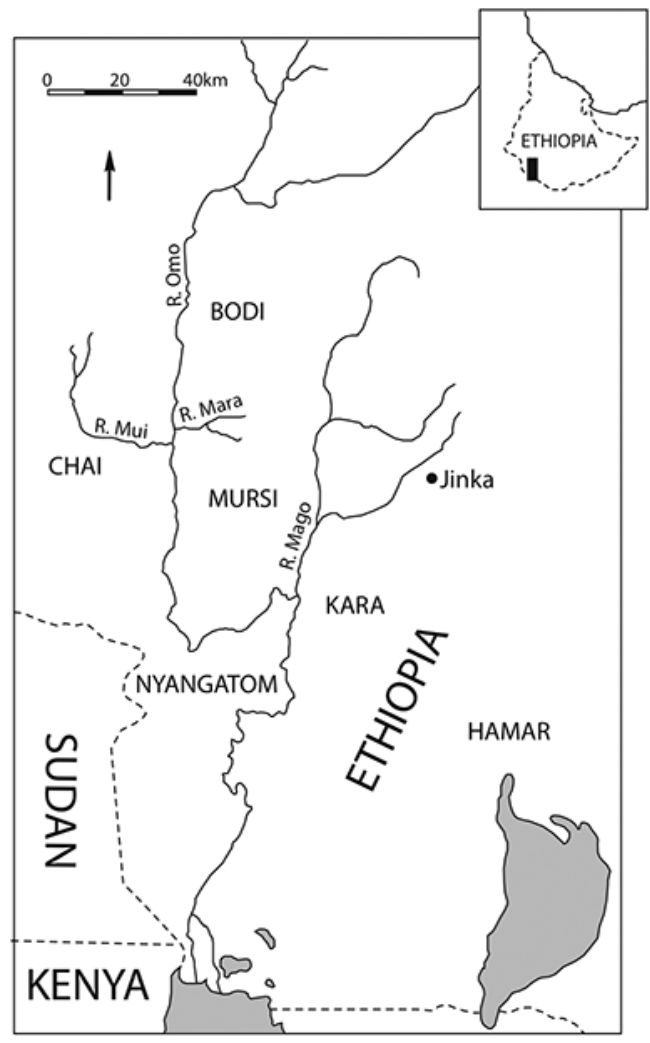

Figure 1. Map indicating the location of Mursi territory and Dirikoro in Ethiopia (adapted from Turton et al. 2008: 2).
Although the Mursi have been the focus of anthropological research, notably by David Turton (e.g. 1973, 1980, 1993, 2004), and the subject of six films directed by Leslie Woodhead (Woodhead 1987, 2014), the archaeology of Mursiland was unknown until the Dirikoro Region was first investigated in 2009 (Clack \& Brittain 2011a \& b). The main feature recorded has been benna kulugto, 'stone circles' that are actually stone platforms constructed from concentric rings of cobbles set on the ground (Figure 2). A horseshoe-shaped cluster, c. $400 \mathrm{~m}$ long and formed of 26 platforms between $2.5 \mathrm{~m}$ and $26 \mathrm{~m}$ in diameter was recorded around the tip of the Arichukgirong Hills (Clack \& Brittain 2011b: 34-35). Each platform had a gulley running usually north-west to the outside edge. This and fragments of burnt bone recovered from between the cobbles suggests the platforms were used for cattle sacrifices and roasting (Brittain \& Clack 2012: 54-55). A single radiocarbon date of $170 \pm 40 \mathrm{BP}$ (cal AD 1650 to 1890 $(2 \sigma)$; Beta-268958) has been obtained. The Mursi do not claim links to the platforms, and oral traditions suggest they pre-date Mursi settlement and might be associated with prior Bodi occupation (Clack \& Brittain 2011a: 88), reflecting the historically fluid nature of ethnicity in the region (Brittain et al. 2013: 136).

'Arichukgirong' means 'snout of the bull' and indicates how the Mursi have used cattle imagery to define and describe aspects of the landscape. That is also evident in two of the five names given to sections of the River Omo: Biogolokare, 'take out the eyes of the cattle'; and (C) Antiquity Publications Ltd, 2015 
Ariholi, 'white ox' (Turton 1973: 102). Cattle also physically alter the landscape through grazing and their overnight corralling in cattle camps, and through the creation of features such as the $c .3 \mathrm{~km}$-long and $c .1 .0-1.5 \mathrm{~m}$-deep drovers' ditch recorded running south-west from the settlement of Meganto. This and the benna kulugto comprise the most significant 'unnatural' features recorded in the landscape. Rock art is so far absent, and cattle and cattle exploitation generate the durable archaeological record in comparison to the ephemeral nature of most Mursi material culture, including the shelters in cattle camps and huts in cultivation settlements (cf. Turton 1973: 83-84; Clack \& Brittain 2011a: 89-90).

Mursi history is also only partially

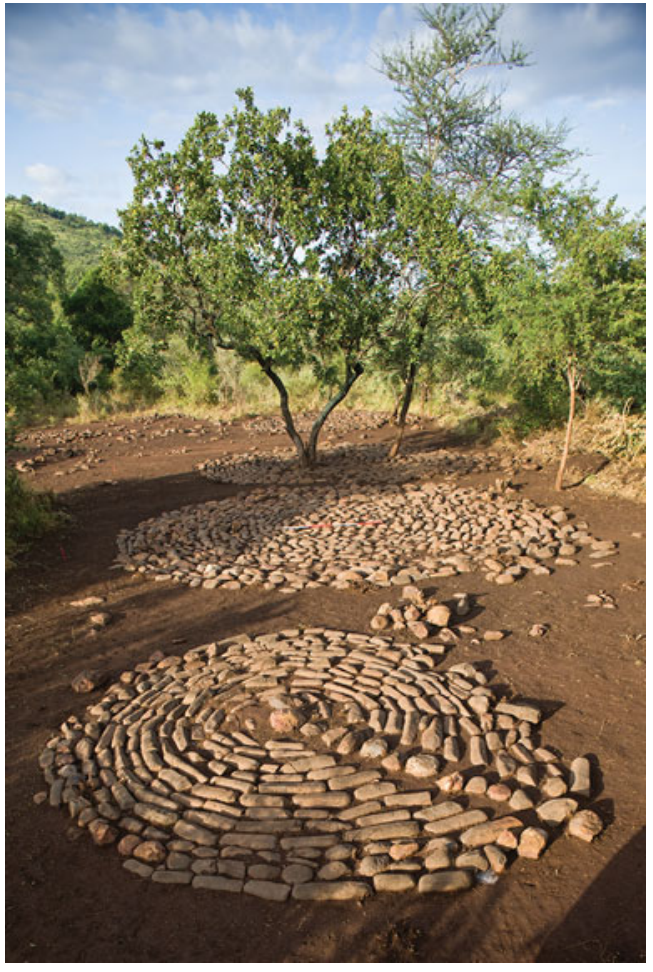

Figure 2. Benna kulugto (stone platform) at Dirikoro. Photograph: T. Clack. understood, and does not indicate when processes such as decorative cattle branding began. The area only became nominally incorporated into the Ethiopian Empire when the troops of Menelik II first occupied the Lower Omo in 1897 (Turton 1973: 31), so there is an absence of written sources. Three phases of migration, however, seem to have contributed to Mursi self-identity (Turton et al. 2008: 1), involving, around 150 years ago, a move east across the River Omo, followed by a migration north in the 1920-30s, and an expansion northeast into the Mago Valley starting in 1979 (Figure 1). Underpinning these was a desire for well-watered grassland for cattle and riverside forest for flood cultivation, primarily of maize and sorghum, to supplement limited rain-fed farming in the bush (Turton 1973: 60).

\section{Cattle significance}

The importance of cultivation to Mursi subsistence should not be downplayed, but the stone platforms, landscape names and migrations reflect the significance of cattle of the Sanga type, which are "dominant" in the region (Abbink 2003: 342). Cattle provide meat and, more commonly, milk and blood for subsistence, but they are also of great cultural importance (Turton et al. 2008: 4). They are the ideal bride-wealth payment, are used in sacrifice, function as the referent for Mursi colour terminology, and provide the linchpin for "the relationship between the sexes, the solidarity of age-mates and the link between the social order and the order of the universe" (Turton 1980: 328). The ritual and social centrality of cattle is not unique to the Mursi, but is widely found amongst pastoralist and agro-pastoralist societies in the region of South Sudan, south-west Ethiopia, northern Kenya and northern Uganda (e.g. Evans-Pritchard 1940, 1956; Gulliver 1952; Lienhardt 1961; 
Almagor 1972; Tornay 1973; Jones 1984; Brown 1990; Fukui 1996; Hazel 1997; Abbink 2003; Dubosson 2013). They are also important elsewhere in Africa (e.g. Herskovits 1926).

This significance of cattle in Mursi society is reflected in the name of one of the authors, Olirege or 'Uli Rêggê'-'Pink Ox'—indicating the relationship between males and 'favourite-ox'. Alternatives for 'favourite-ox' include 'personal-ox', 'display-ox', 'bell-ox', 'song-ox', 'name-ox' and 'parade ox' (boeuf de parade) (e.g. Evans-Pritchard 1940: 18, 1956: 250; Gulliver 1952: 72; Lienhardt 1961: 17; Almagor 1972: 79; Tornay 1973: 87; Burton 1980: 276; Brown 1990: 60; Coote 1992: 252; Hazel 1997: 68; Dubosson 2013: 82).

\section{Ox modification}

The 'favourite-ox' can be beautified via modification in varied ways; breeding for coat colour (Turton 1980; Coote 1992; Fukui 1996), castration (Evans-Pritchard 1956; Coote 1992; Dubosson 2013), ear cutting (Almagor 1972; Dubosson 2013), horn shaping (EvansPritchard 1940; Gulliver 1952; Brown 1990; Abbink 2003; Dubosson 2013), the wearing of secondary ornaments such as bells around the neck (Evans-Pritchard 1956), excision of part of the pendulous neck to resemble the foreskin after circumcision (Almagor 1972), pulling out the hump behind the neck to encourage its growth (Evans-Pritchard 1937), or pattern branding, the particular focus here. All except neck excision and hump pulling were recorded amongst the Mursi.

Ox decoration through modification is completed to make the animal special and beautiful. As Dubosson (2013: 83) notes with reference to Hamar decorated cattle, "le bovin quitte la sphere des animaux domestiques pour entrer dans une autre plus proche de celle des humains" ["cattle leave the sphere of domestic animals to enter a realm much closer to that of humans"]. It also radically changes the form of the ox, altering it to the extent that it could be perceived either as more or less ox-like depending on the observer. Emic perspectives, focusing on the views of the local people, seem to see the modified ox as an enhanced ox, the exemplar of its kind. From an etic (outside ethnographic) perspective, it seems to us that the ox begins to cease to be ox-like and becomes more of a fantasy creature. Yet perhaps such a division is slightly simplistic, for both the aesthetic and fantastic qualities of the modified ox are recognised by the Mursi, as with other cattle-keeping peoples in the region (Coote 1992: 254).

\section{Pattern branding}

A favourite castrated ox of 3-4 years of age and of pink or white colour will usually be pattern branded. A skilled 47-year-old male elder completed the pattern branding recorded at Doribiscini bhuran (cattle camp-N05.72069 ${ }^{\circ}$ E $036.10448^{\circ}$ ). The branding was done with a chisel-like iron tool, the baera (Figure 3), which was obtained by trade from Aari blacksmiths in the regional centre of Jinka. Green wooden stakes $c .0 .5-0.6 \mathrm{~m}$ in length with bark removed and sharpened to a point at one end were used as handles. These were possibly Cordia gharaf, Mursi loi, often used as handles and "firesticks" (Turton et al. 2008: 121). The baera was heated in a continuously blazing hot fire maintained by an assistant.

(C) Antiquity Publications Ltd, 2015 

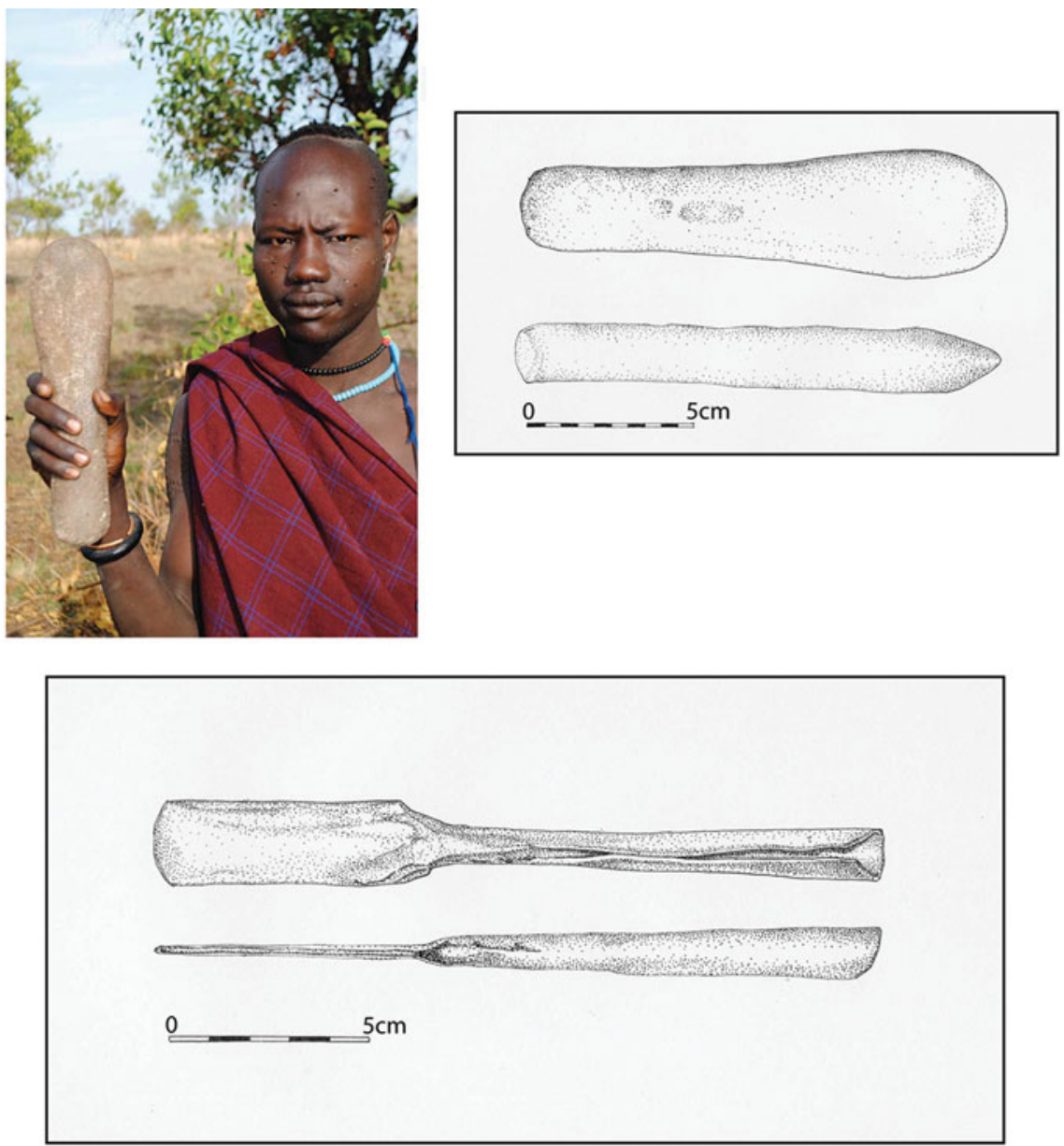

Figure 3. Tools used for horn modification and pattern branding: top left) cattle herdsman holding horn-shaping hammer; top right) Be' bhêy Kara Nun, ground-stone horn-shaping hammer; bottom) baera, iron branding tool. Photograph: T. Insoll.

During the branding two men restrained the ox laying on its side by sitting on its upper chest; others held ropes to the legs (Figure 4). The baera was retrieved from the fire using one of the green wooden handles and tapped into place on a large branch situated between the fire and the ox. The red-hot baera was moved in a continuous linear motion across the skin until it had cooled and was no longer effective (Figure 4). This allowed approximately $0.6-0.8 \mathrm{~m}$ of branded line or 20 seconds of working time between reheating. The two rear flanks around the anus were completed with missirou patterns, one of three types of decoration described as routinely applied (Figures $4 \& 5$ ). Missirou is composed of five concentric circular lines ringing the tail and anus. The other, miren, is of two types: three concentric circles, and a double 'U' (Figure 5).

Pattern branding ceased once the ox was perceived to be distressed. The branded areas were then medicated with chulloi, fresh cow dung, and the ox was allowed to recover in 


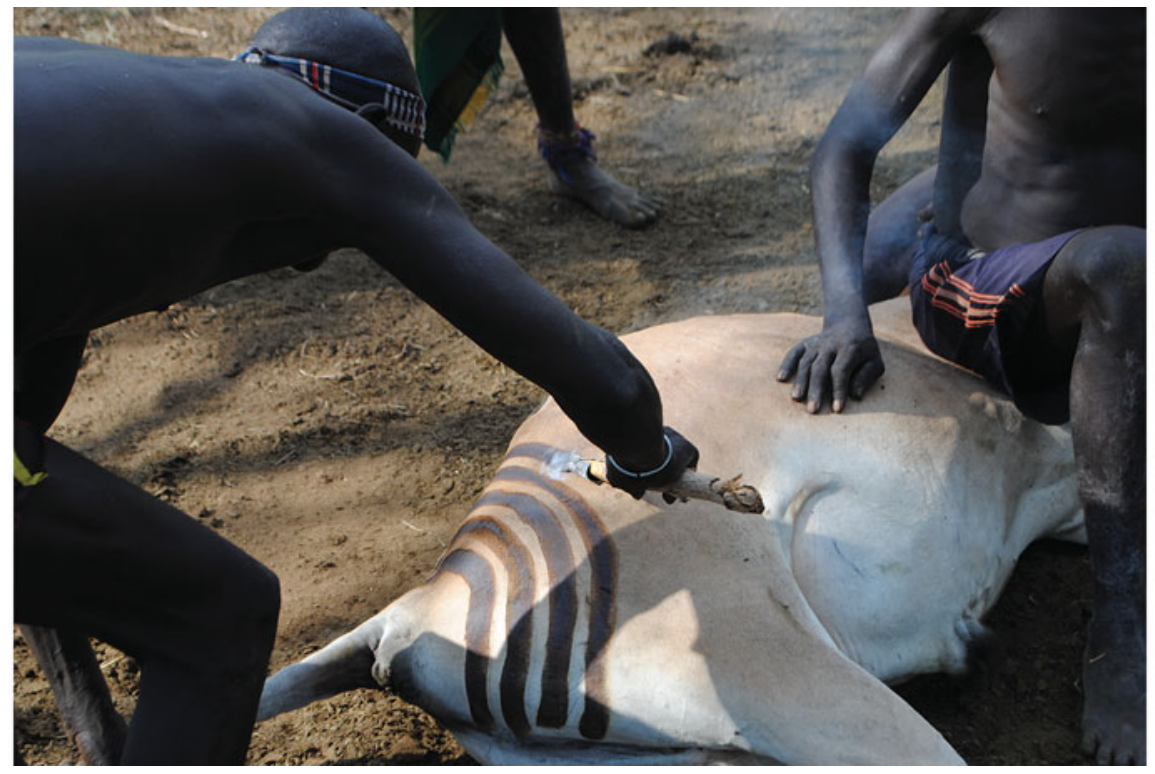

Figure 4. Branding the missirou decoration using the baera. Photograph: T. Insoll.

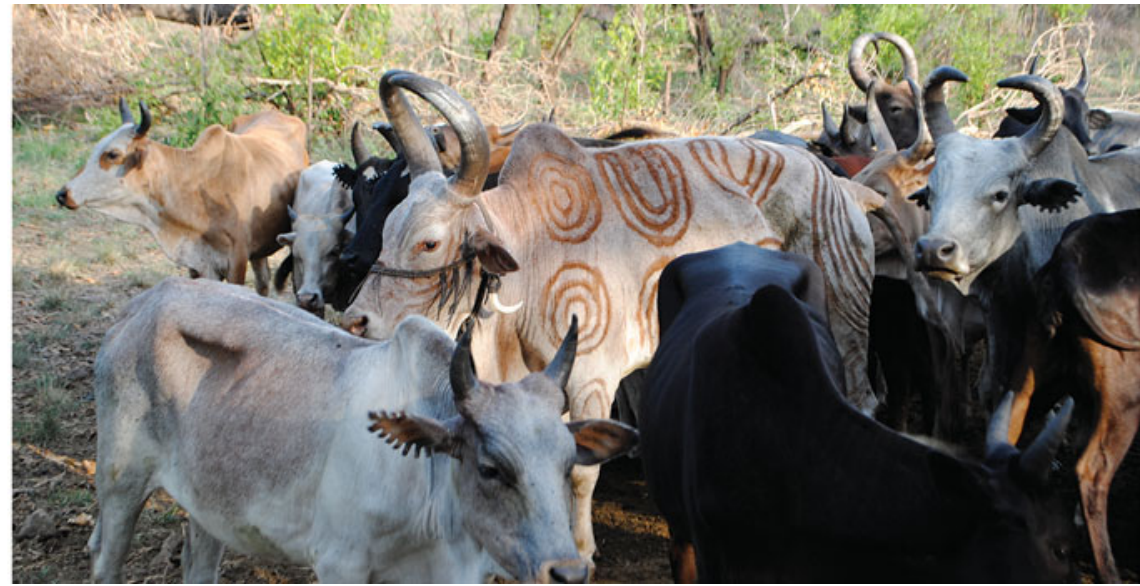

Figure 5. Fully decorated ox with chipto horns, nilla ornaments and left to right: concentric circular miren, double ' $U$ ' miren and missirou branded decoration. Photograph: T. Insoll.

the nursery area of the bhuran. Later the same day the branded ox was ritually medicated for apotropaic reasons with bile from another ox killed by a blow to the head from a stone to obtain its gall bladder. Depending on the resilience of the ox and the urgency of other activities, pattern branding is continued a few days or weeks later. After the death of a pattern branded ox, its skin, like those of other cattle, will be used to make a hada (sleeping mat). Branded hada are not deemed ritually significant but their aesthetic qualities are recognised and enhance demand.

(C) Antiquity Publications Ltd, 2015 
Comparative data on decorative pattern branding is sparse. The Hamar decorate favourite oxen, errawak, by branding with a lance to produce either curved or straight lines in varied patterns (Dubosson 2013: 83). No other information is provided. Russell (2012: 7, fig. 3) also provides an illustration (without giving details) of the favourite goat of a Turkana man who did not own cattle or camels. The goat is branded on one side with missirou-type decoration at the rear, a central vertical ladder-like band, and variously sized semi-circular lines running downwards from the front chest to the upper foreleg. One ear is also cut in a nyabacouda-type pattern, described below.

\section{Wider significance of pattern branding}

Ox pattern branding seemingly relates to another dominant domain of Mursi materiality: the human body itself. Eczet and Poissonnier (2013: 187) note the parallels between the miren double ' $U$ ' symbol and its use in riru scarification. Riru is the marking for men who have killed enemies in combat, perhaps in connection with cattle raids, and the riru marks are made on the arm with a spear point "rougie au feu" (Eczet \& Poissonnier 2013: 181). Heat as the medium for bodily transformation appears to link ox and man, as do the symbols and the use of the masculine number four (three being female), as in four miren double 'U's being branded on the ox (Figure 5). This is not, however, a simple process of mimicry, as the double ' $U$ ' in riru is often inverted (Eczet \& Poissonnier 2013: 185) (Figure 6).

Kichoa is the other system of Mursi scarification. This is applied to upper body areas such as the torso, arms, back, stomach and breasts. It seems to lack either missirou or miren symbols, perhaps because kichoa is applied to both men and women. For example, the use of concentric circles as double dashed lines around the nipple (Figure 6) differs from circular miren. The technique used also varies, as kichoa is formed of keloids cut with a razor after lifting the flesh with a thorn (cf. Eczet \& Poissonnier 2013), rather than branding. Continuous composite scars, including double concentric circles, can also form part of kichoa, so too strict a demarcation is perhaps unwise. Less permanent bodily transformations that are perhaps more plausibly linked to miren symbols are concentric circles shaved into male hairstyles (Figure 6).

In other respects, Mursi material culture is limited (e.g. Turton 1973, 1980; Eczet \& Poissonier 2013), but symbolic references to ox pattern branding can be suggested on other Mursi objects. The Kalashnikov AK-47 rifle and variants thereof is another component of Mursi masculinity today (Turton 1993). Painted designs on stocks and fore-grips include the inverted double ' $U$ ' miren decoration (Figure 6). These rifles were first introduced in the 1980s (Turton 1993) and attest how Mursi traditions of pattern branding, aesthetics, ornamentation, and material and human decoration do not exist in a historical and political vacuum but are re-employed as new material culture and contact zones are encountered. This is also evident in the depiction of miren and missirou patterns on stylised clay figurines made by some Mursi women for sale to tourists over the last 10 years (Figure 7). Finally, although seemingly not linked to the Mursi, the repeating concentric circles of stones in the benna kulugto described above form features that conceivably functioned for cattle sacrifice in the past, and more generally link circles and cattle. 
Mursi ox modification in the Lower Omo Valley and the interpretation of cattle rock art in Ethiopia
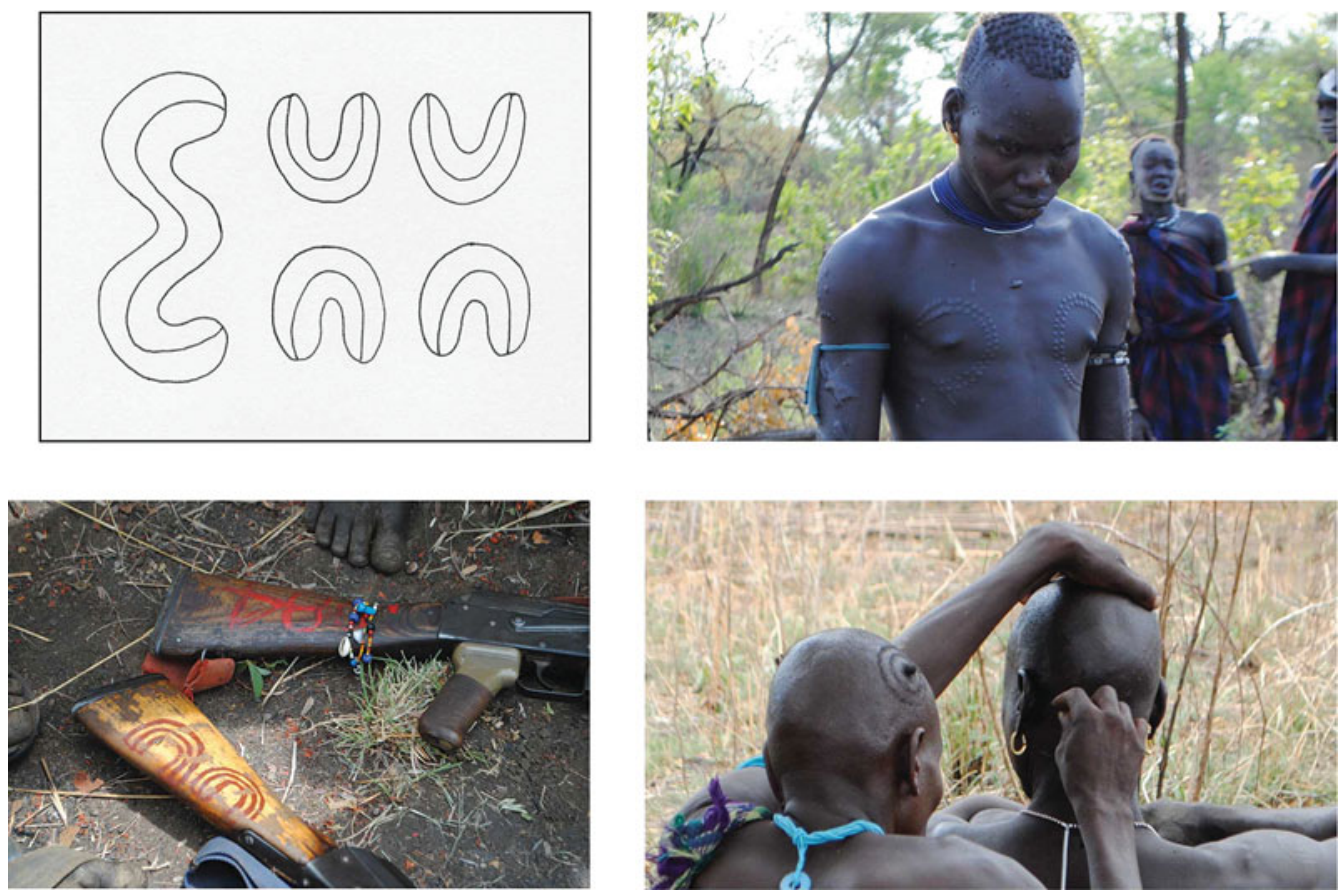

Figure 6. Top left) riru double 'U' symbols (after Eczet \& Poissonnier 2013: 182); top right) kichoa concentric circle decoration around nipple; bottom left) decorated Kalashnikovs, rear with beads, cowrie shells, red paint and leather pistol grip cover, front with red-painted inverted double ' $U$ ' miren symbols; bottom right) concentric circle hair decoration. Photographs: T. Insoll.

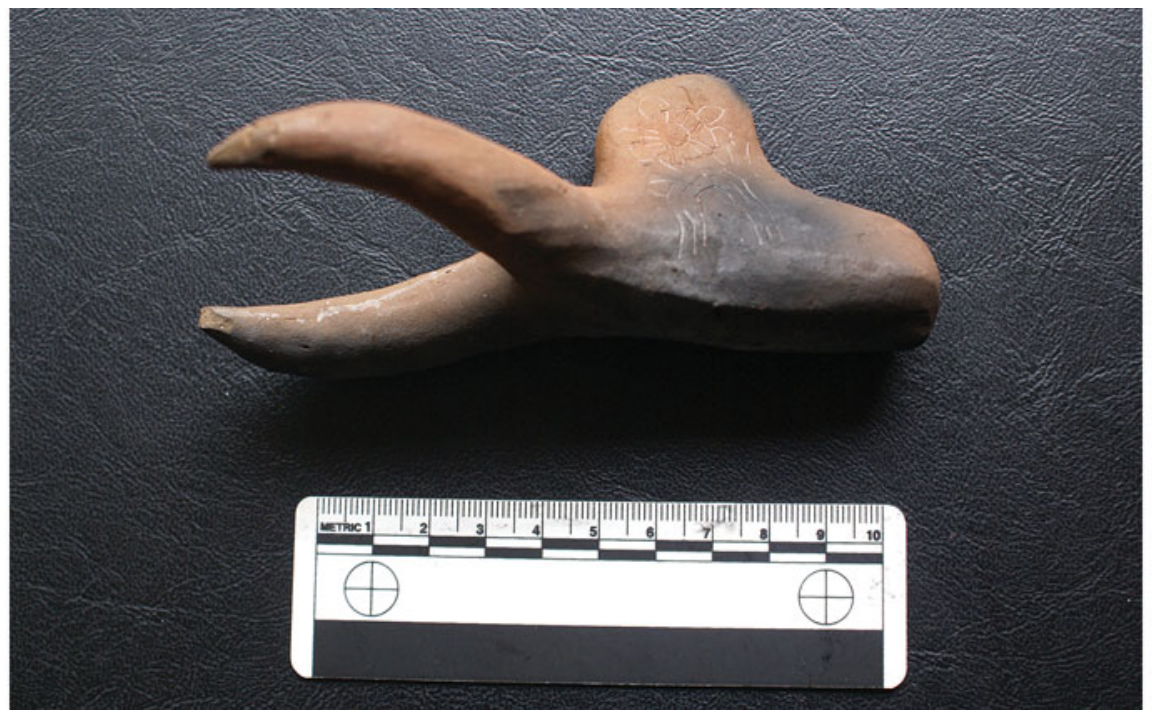

Figure 7. Mursi oliyna, clay cattle figurine with incised double 'U' miren. Photograph: T. Clack.

(C) Antiquity Publications Ltd, 2015 


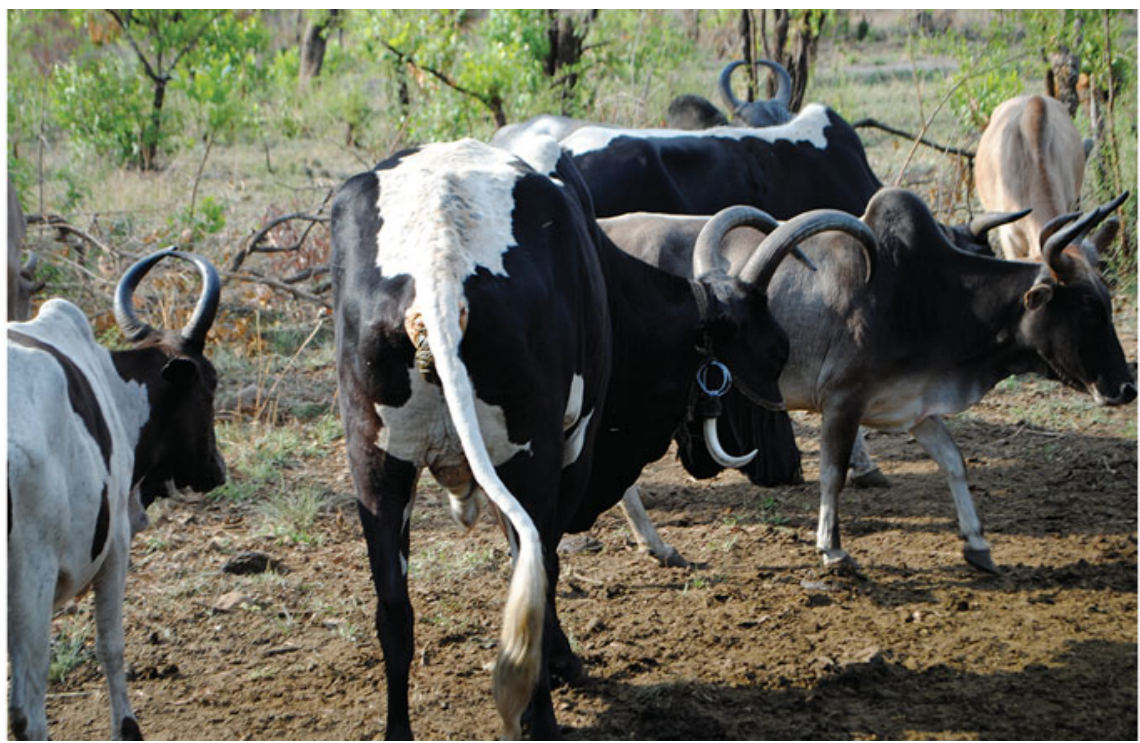

Figure 8. Balai colour (contrasting) black and white ox with dogomme horn pattern. Photograph: T. Insoll.

\section{Horn shaping}

Horn shaping is also a significant form of Mursi ox modification. Three modified horn shapes were identified in the herds at Doribiscini: dogomme forward-shaped horns (Figure 8); and two variants of the chipto inward-curved horn shape (Figure 9). The horn shaping was completed by the same elder as the pattern branding using a ground sandstone hammer, $B e^{\prime}$ bhêy Kara Nun. These are locally manufactured and are only used for horn shaping, but like the baera are not ritually important. A worn lower grinding stone, golu, is used to make a horn-shaping hammer. This is initially pecked into shape with a basalt cobble and then filed with a flat face of the same basalt tool to obtain the smooth surface finish of the hammer (Figure 3).

The ox was restrained in the same way as for branding with ropes attached to the legs, but with a man sitting on its flank and another holding its head. Carefully aimed blows of the stone hammer from various positions around the head were used to break the base of the horn where it joined the skull (Figure 10). Once loosened in this way, the horns were cut with a circular V-shaped notch below the tip and bound tightly together with twine to keep the position and encourage horn growth in the desired shape. The horns and surrounding area of the skull were medicated with chulloi and the ox again recovered in the bhuran nursery area. Similar processes of horn shaping have been described for the Turkana and Pokot in Kenya (Jones 1984: 46; Brown 1990: 61-63), and the Karamojong in Uganda (Gulliver 1952: 72).

\section{Other modifications}

In addition to cattle breeding for coat colour and castration (cf. Turton 1980), which were not the focus of this research, ear cutting and the wearing of secondary ornaments 


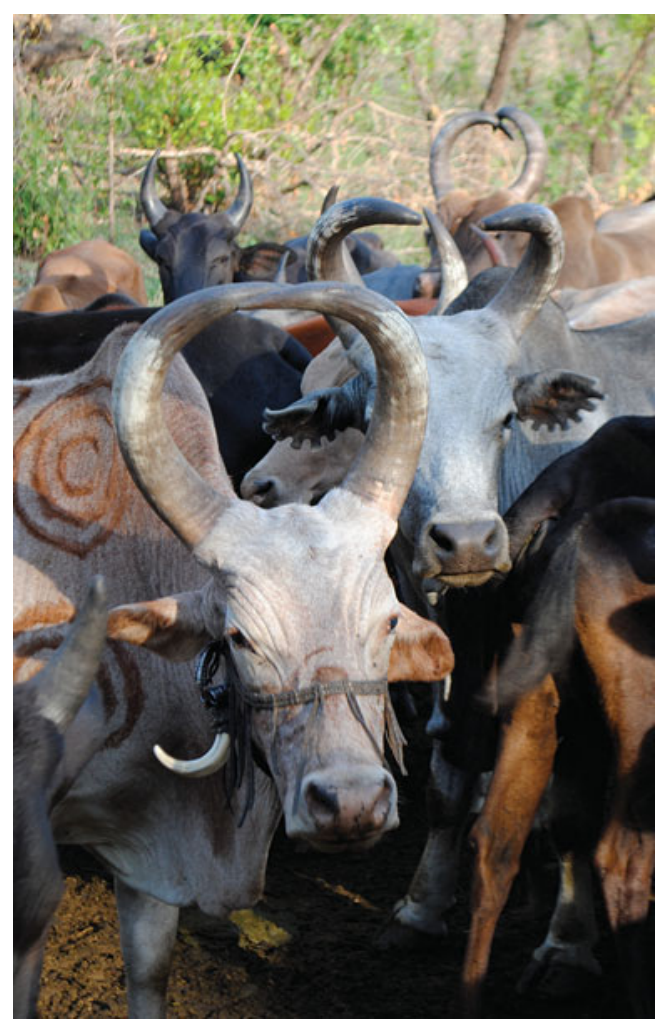

Figure 9. Decorated oxen: front) branded ox wearing nilla ornaments with chipto horn pattern; behind) gidangi (dirty whitelgrey) oxen with variant of chipto and nyabacouda ear decoration. Photograph: T. Insoll. are further forms of Mursi cattle modification. Decorating the ears can be done for either cows or oxen, and has two forms based on the extent of cutting. Nyabacouda is a rounded, serrated saw-tooth pattern around either one or both ears (Figure 9); sierouy is a more pronounced form where the ear is cut into four upward points. The latter was not seen during this particular fieldwork. These patterns are cut with the small arrow, lawun wheni, used for letting blood from cattle's main veins for human consumption. Often the same male elder who does the horn alteration and pattern branding will complete the ear cutting.

A secondary ornament used by the Mursi to decorate oxen, nilla, is made locally by Mursi men from leather and two warthog (Phacochoerus africanus) tusks joined with iron fittings to a leather headpiece (Figure 9). These are worn so that the tusks are positioned pointing outwards from either side of the ox's head below the ears, providing a visual contrast in both size and colour to the ox horns.

\section{Cattle modification and rock art in Ethiopia}

Ethiopian rock art was sampled for representations of cattle modification based on the high proportion of cattle images present (e.g. Brandt \& Carder 1987; Hundie 2001; Le Quellec \& Abegaz 2001; Mire 2008; Hagos 2011) (Figure 11). It is possible that relevant images also exist in the rock arts of Somalia, Somaliland and Djibouti, but nothing has so far been found. Overall, pastoral rock art has been described as "a comparatively recent phenomenon" (Brandt \& Carder 1987: 195) in the Horn of Africa, including Ethiopia, spanning the last $4000-5000$ years. No indication of cattle ear-cutting or the wearing of ornaments analogous to nilla was found in Ethiopian rock art.

\section{Horn shaping}

Horn shaping, however, may be represented (cf. Huard 1959: 114). For instance, at the site of Anza 1,30km east of Edaga Hamus in Tigray, two cattle paintings might depict this. One is approximately $200 \mathrm{~mm}$ in length and has exceptionally 'diverged' horns (Figure 11.6), and the other, although indistinct and partly damaged, has 'twisted' forward- and downwardpointing horns (not illustrated) (Nigus 2006: 59-60). Both were dated on stylistic grounds (C) Antiquity Publications Ltd, 2015 


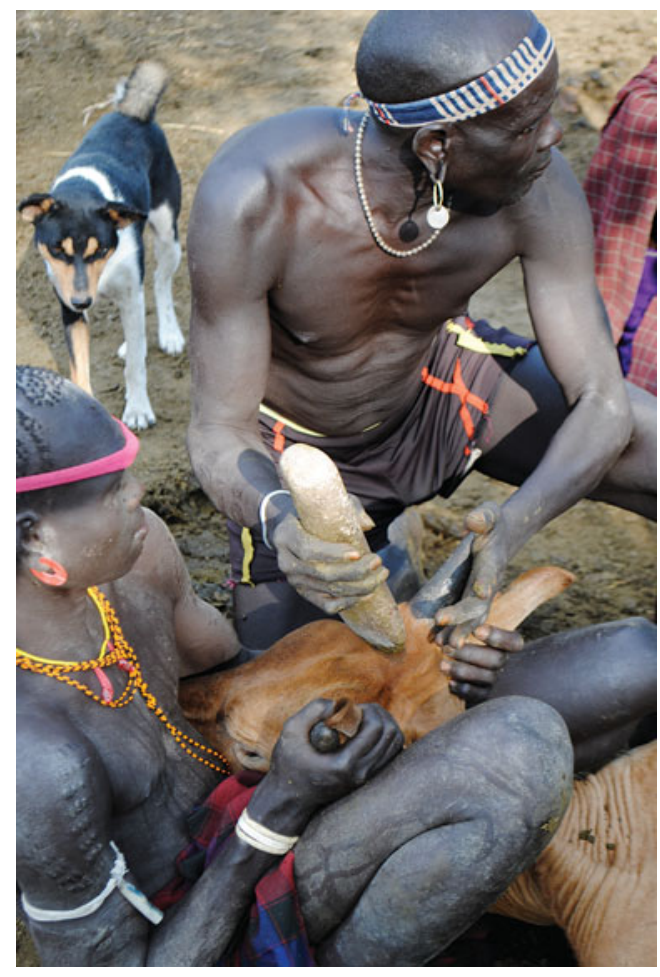

Figure 10. Horn shaping in progress. Photograph: T. Insoll. to between 5000-3000 BP. Hagos (2011: 13) also refers to this emphasis given to horn shapes in Ethiopian rock art, as "twisted or deformed or in abnormal positioning both downward- and forward-curving and high arching of the horns", but without linking it to horn shaping.

The asymmetrical horns present on a humpless longhorn cattle engraving, part of a panel $c .3 \mathrm{~m}$ long $\times 2.3 \mathrm{~m}$ wide, at Ejersa Gara Halla in the Dilla area, have also been interpreted as depicting a modified horn form (Figure 11.7). Le Quellec and Abegaz (2001: 206) suggest these are like the Hamar modified horn style known as kamara, where one horn bends forward and the other upward. This engraving has been placed within the Sappé-Galma School that was broadly dated to between $c .6500$ and $2500 \mathrm{BP}$, but with the proviso added that they "could be much more recent" (Le Quellec \& Abegaz 2001: 211).

Horn shaping has been previously suggested for Saharan images (e.g. Huard 1959; Cervicek 1971: 131; Dupuy 1999: 58; Chaix 2006: 49-50; Lenssen-Erz 2012: 95; Dubosson 2013: 86) where a high incidence of bovine images is also present (Le Quellec 1998: 66-67). In the Sahara, the beginnings of cattle pastoralist rock art have been dated to the second half of the seventh millennium BP, and are part of the emergence of a 'cattle cult' (Muzzolini 2000: 89; di Lernia 2006: 60; Le Quellec 2013: 34).

\section{Decorative pattern branding}

It is possible that decorative pattern branding is depicted on some cattle in rock paintings from Ethiopia and neighbouring Eritrea. At the Laga Oda rockshelter, $25 \mathrm{~km}$ south-west of Dire Dawa, a painting of a cow provides the strongest evidence for such modification. The image is $360 \mathrm{~mm}$ in length and forms one part of a panel of eight pictures of cattle. It is described by Cervicek (1971: 122) as "painted in a darkened white, [with] the contours, the inner pattern, horns and udder in black" (Figure 11.5). Cervicek does not consider why the cow is decorated in this way, but the neatly painted geometric patterns could indicate decorative pattern branding. Other strong possibilities are provided by the "distinctive patchy markings, usually in brown and reddish tones, possibly also representing cattle brands" referred to by Marshall (2000: 197). These are depicted on paintings of humpless cattle at Zeban Ona Libanos and Sollum Ba'atti in Eritrea that lack dates. Marshall does not specify the type of branding, but decorative pattern branding seems likely.

(C) Antiquity Publications Ltd, 2015 

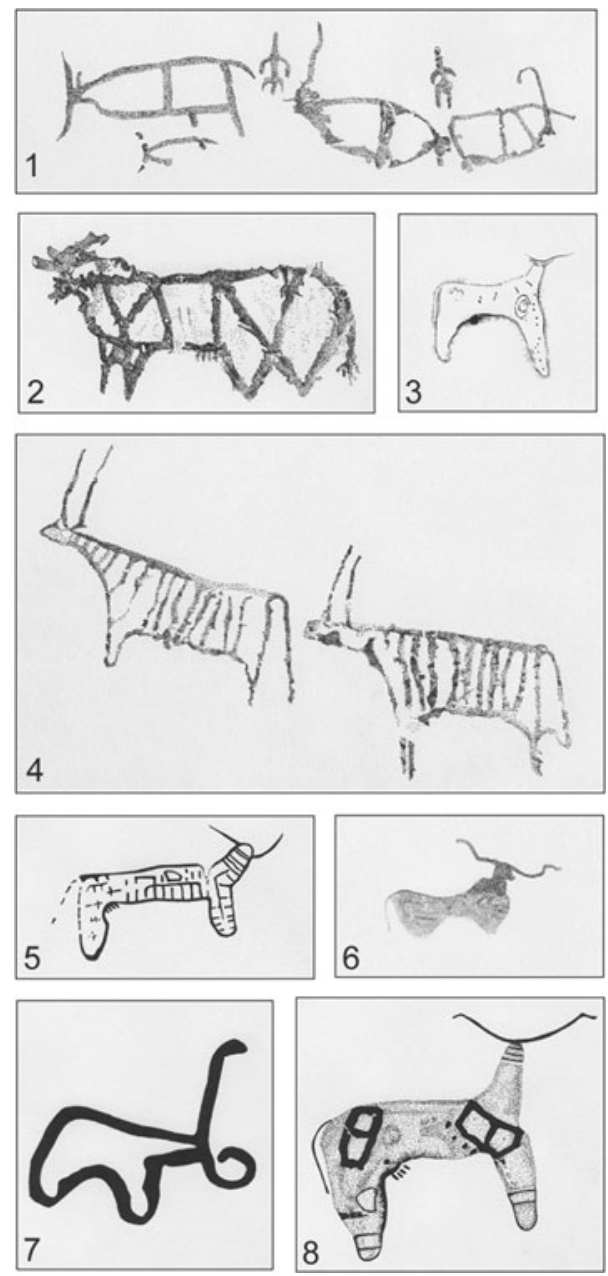

Figure 11. Top to bottom, not to scale: 1) bovid paintings with single or double stripes down the centre of the body, Laga Gafra (after Cervicek \& Braukämper 1975: fig. 4); 2) cattle painting with geometric coat markings, Adi Qanza, Eritrea (after Graziosi 1964: pl. 15); 3) cow painting with circular markings, dots and lines, Laga Oda (after Cervicek 1971: fig. 9); 4) cattle paintings with vertical banding on coats, Sollum Ba'atti, Eritrea (after Graziosi 1964: pl. 13); 5) cow painting with a geometric coat pattern, Laga Oda (after Cervicek 1971: 191): 6) cattle painting with "exceptionally diverged", possibly trained horns, Anza 1 (after Nigus 2006: 59); 7) longhorn cattle engraving with asymmetrical horns, Ejersa Gara Halla (after Le Quellec \& Abegaz 2001: fig. 7); 8) cow painting with two bisected rectangles, one with associated dashes, Laga Oda (after Cervicek 1971: fig. 4).
At the Sollum Ba'atti rockshelter, for example, two of the cattle are depicted with vertical banding that could be decorative pattern branding (Figure 11.4). The dimensions of the images are not given, but the total painted area is described as $18 \mathrm{~m}$ wide $\times 2-3 \mathrm{~m}$ high (Graziosi 1964: 93). Dimensions are also unstated for the images at the Adi Qanza rockshelter where a red-painted bovid accompanied by a man armed with a spear (Graziosi 1964: 97) again has interesting geometric coat markings that could denote pattern branding (Figure 11.2).

Cervicek (1971: 124) refers to the presence of "two circular markings (brands)?" painted in red on another cow, $0.58 \mathrm{~m}$ long and depicted in black outline at Laga Oda (Figure 11.3). Taking the circular markings singularly, these could be interpreted as ownership brands rather than decorative patterns. Elsewhere in the Horn and eastern Africa ownership brands have been linked to rock art (e.g. Phillipson 1977: 272; Brandt \& Carder 1987: 198; Finneran 2007: 105; Dubosson 2013: 84). An example is provided by the almost 1000 geometric rock engravings recorded on the lava outcrops surrounding, and stone upright slabs associated with, graves at the Namoratunga cemetery and rock art site near Lake Turkana in northern Kenya (Lynch \& Robbins 1977). This is an interpretation, however, that has been challenged recently (cf. Russell \& Kiura 2011; Russell 2012).

Not referred to by Cervicek (1971: 124) are the lines and dots depicted on the same animal at Laga Oda (Figure 11.3). In totality, these motifs could indicate pattern branding, though of a different form to the geometrically decorated example at the same site. Branding could also be represented on a third cow from the site. This is painted in light grey with black details and is $470 \mathrm{~mm}$ in length (Cervicek 1971: 123). Two rectangles bisected by a vertical line, one with associated (C) Antiquity Publications Ltd, 2015 
dashes underneath, could indicate ownership or be for aesthetic purposes (Figure 11.8). All the images (approximately 600 in total) at Laga Oda were originally placed within the so-called 'Ethiopian-Arabian' style, dated to between 2200 and 1550 BC (Cervicek 1971: 130,143 ), based on stylistic affinities with C-Group pottery from Nubia (Brandt \& Carder 1987: 206). These dates have, however, been questioned by Le Quellec and Abegaz (2001: 211; see also Le Quellec 2003) who indicate that archaeological remains of domesticated cattle do not pre-date $3500 \mathrm{BP}$, suggesting the images are later in date.

In describing a panel of three larger painted 'bovids' and associated human figures $(0.6 \mathrm{~m}$ wide) at the rockshelter of Laga Gafra, another 'Ethiopian-Arabian' rock painting site south-west of Harar, Cervicek and Braukämper (1975: 51) make oblique reference to decorative branding. They suggest that the single or double vertical stripes depicted running down the centre of the bovid bodies (Figure 11.1) are reminiscent "of modern burnt ornaments of cattle as applied by East African cattle breeders". The alternative, less plausible interpretation they suggest is that they represent the wearing of bead bands. A similar cattle rock painting with a vertical stripe down the centre of the body is depicted at Amba Fekada II in Tigray (Nigus 2006: 42).

It has been argued that decorative pattern branding may be represented in Saharan rock art (e.g. Dubosson 2013: 87). For example, Dupuy (1998: 51; 1999: 71) has drawn brief attention to Fulani cattle whose coats were painted with crude vertical, horizontal and slanting lines and spots in the Diafarabé region of Mali as a possible analogy for the geometric signs engraved on some cattle rock art (age unspecified) in the Adrar des Iforas Mountains in northern Mali. Lenssen-Erz (2012: 105) also refers to some of the cattle rock painting and engraving images in the Ennedi Highlands of north-east Chad as being individualised "with very intricate, 'costly' patterns of the coat often in strictly unnatural geometric designs", this fitting "with current patterns of behaviour among some cattle pastoralists". The existence of potentially comparable practices elsewhere in African prehistory strengthens the hypothesis advanced here for interpreting aspects of Ethiopian cattle rock art.

\section{Conclusions}

Mursi pattern-branding practices suggest that in some cases the abstract or non-realistic symbols depicted on cattle coats in Ethiopian rock art could be read more literally. They could signify actual processes of decorative branding (or painting or scarifying) to modify, alter or beautify cattle. Mursi missirou and miren symbols also provide a cautionary note in relation to neuro-psychological interpretations of rock art imagery and their potentially universal applicability. The circular and double ' $U$ ' could be misinterpreted as entoptic phenomena. These may not precisely parallel trance-related symbols but are generically similar and could be seen, either when represented with or without cattle, as 'shamanic' or 'trance' related, when they are not (cf. Finneran 2007: 105 for a relevant critique in the Ethiopian context). Instead, they may be indicative of wholly unconnected and complex patterns of human-animal relations centred on masculinity and aesthetics.

\section{Acknowledgements}

Timothy Insoll is grateful to the University of Manchester for funding his participation in the fieldwork. Timothy Clack acknowledges fieldwork support from the British Academy and the Christensen Fund linked to elements 
of this work. All the authors are grateful to the Ethiopian Authority for Research and Conservation of Cultural Heritage for permission to complete the fieldwork. They are also indebted to Ato Abebe Hailu, Antiquities Officer; Mr Juan Salazar Bonet for assistance in the field; and to the Mursi communities in Dirikoro for their hospitality. Paul Bahn, Rachel MacLean, Jean-Loïc Le Quellec, Julian Thomas and David Turton are thanked for comments on the paper, but all errors and omissions remain our own. Rachel MacLean is thanked for doing the line drawings and Ceri Houlbrook and Bryn James are gratefully acknowledged for putting some of the illustrations together digitally.

\section{References}

ABBINK, J. 2003. Love and death of cattle: the paradox in Suri attitudes toward livestock. Ethnos 68: 341-64.

Almagor, U. 1972. Name-oxen and ox-names among the Dassanetch of southwest Ethiopia. Paideuma 18: 79-96.

Bolton, M. 1976. Ethiopian wildlands. London: Collins \& Harvill.

BrandT, S. \& N. Carder. 1987. Pastoral rock art in the Horn of Africa: making sense of udder chaos. World Archaeology 19: 194-213.

BritTAin, M. \& T. ClaCK. 2012. Archaeological and ethno-historical investigations in Mursiland, S.W. Ethiopia: second interim report. Nyame Akuma 78: 41-57.

Brittain, M., T. Clack \& J.S. Bonet. 2013. Hybridity at the contact zone: ethnoarchaeological perspectives from the Lower Omo Valley, Ethiopia. Archaeological Review from Cambridge 28: 133-50.

BROWN, J. 1990. Horn-shaping ground-stone axe-hammers. Azania 25: 57-67.

BurTON, J. 1980. The village and the cattle camp. Aspects of Atuot religion, in I. Karp \& C.S. Bird (ed.) Explorations in African systems of thought: 268-97. Bloomington: Indiana University Press.

CerviceK, P. 1971. Rock paintings of Laga Oda (Ethiopia). Paideuma 17: 121-36.

Cervicek, P. \& U. Braukämper. 1975. Rock paintings of Laga Gafra (Ethiopia). Paideuma 21: 47-60.

CHAIX, L. 2006. Bœufs à cornes déformées et béliers à sphéroïde: de l'art rupestre à l'archéozoologie, in Y. Gauthier, J.-L. Le Quellec \& R. Simonis (ed.) Hic sunt leones. Mélanges Sahariens en l'honneur d'Alfred Muzzolini (Cahiers de l'AARS 10): 49-54.

St-Benoist-sur-Mer: Association des Amis de l'Art Rupestre Saharien.

Clack, T. \& M. Brittain. 2011a. Place-making, participative archaeologies and Mursi megaliths: some implications for aspects of pre- and proto-history in the Horn of Africa. Journal of East African Studies 5: 85-107.

- 2011b. When climate changes: megaliths, migrations, and medicines in Mursiland. Current World Archaeology 46: 32-39.

Coote, J. 1992. 'Marvels of everyday vision': the anthropology of aesthetics and the cattle-keeping Nilotes, in J. Coote \& A. Shelton (ed.) Anthropology, art and aesthetics: 245-73. Oxford: Clarendon.

DI LERNIA, S. 2006. Building monuments, creating identity: cattle cult as a social response to rapid environmental changes in the Holocene Sahara. Quaternary International 151: 50-62.

Dubosson, J. 2013. Esthétique et symbolique du bétail dans l'art rupestre: l'apport de l'anthropologie (Cahiers de l'AARS 16): 81-92. Benoist-sur-Mer: Association des Amis de l'Art Rupestre Saharien.

DupuY, C. 1998. Réflexion sur l'identité des guerriers représentés dans les fravures rupestres de l'Adrar des Iforas et de l'Aïr. Sahara 10: 31-54.

- 1999. Les apports de l'archéologie et de l'ethnologie à la connaissance de l'histoire ancienne des Peuls, in R. Botte, J. Boutrais \& J. Schmitz (ed.) Figures Peules: 53-72. Paris: Karthala.

ECZET, J.-B. \& B. Poissonnier. 2013. Décors mobiliers médiévaux et décors corporels actuels: exercice comparatif ethnoarchaéologique Shay/Mursi, in F.-X. Fauvelle-Aymar \& B. Poissonnier (ed.) La culture Shay d'Éthiopie. Recherches archéologiques et historiques sur une elite païenne: 175-90. Addis Ababa: Centre Français des Études Éthiopiennes.

EVANS-PRITCHARD, E.E. 1937. Economic life of the Nuer: cattle. Sudan Notes and Records 20: 209-45.

- 1940. The Nuer. Oxford: Clarendon.

- 1956. Nuer religion. Oxford: Clarendon.

FINNERAN, N. 2007. The archaeology of Ethiopia. London: Routledge.

FUKUI, K. 1996. Co-evolution between humans and domesticates: the cultural selection of animal coat colour diversity among the Bodi, in R. Ellen \& K. Fukui (ed.) Redefining nature: 319-85. Oxford: Berg.

Graziosi, P. 1964. New discoveries of rock paintings in Ethiopia. Antiquity 38: 91-98.

Gulliver, P.H. 1952. Bell-oxen and ox-names among the Jie. Uganda Journal 16: 72-75.

Hagos, T. 2011. The Ethiopian rock arts: the fragile resources. Addis Ababa: Authority for Research and Conservation of Cultural Heritage.

(C) Antiquity Publications Ltd, 2015 
Hazel, R. 1997. Robes colorées et cornes déformées: ses pasteurs est-africains et leurs boeufs de parade. Anthropologie et Sociétés 21: 67-85.

Herskovits, M.J. 1926. The cattle complex in East Africa. American Anthropologist 28: 361-88.

HuARD, P. 1959. Les cornes déformées sur les gravures rupestres du Sahara sud-oriental. Travaux de l'Institut de Recherches Sahariennes 18: 109-31.

Hundie, G. 2001. The emergence of prehistoric pastoralism in southern Ethiopia. Unpublished $\mathrm{PhD}$ dissertation, University of Florida.

JONES, D.K. 1984. Shepherds of the desert. London: Elm Tree.

LENSSEN-ERZ, T. 2012. Adaptation or aesthetic alleviation: what kind of evolution do we see in Saharan herder rock art of northeast Chad? Cambridge Archaeological Journal 22: 89-114.

LE QueLLEC, J.-L. 1998. Art rupestre et préhistoire du Sahara. Paris: Payot.

- 2003. L'Art rupestre de style dit 'Arabo-éthiopien' et l'école de Chabbè-Galma. Afrique-Archéologie-Arts 2: 47-68.

- 2013. Périodisation et chronologie des images rupestres du Sahara Central. Préhistoires Méditerrannéennes 4: 2-45.

Le Quellec, J.-L. \& G. Abegaz. 2001. New sites of south Ethiopian rock engravings: Godana Kinjo, Ejersa Gara Hallo, Laga Harro, and remarks on the Sappé-Galma school. Annales d'Ethiopie 17: 205-24.

Lienhardt, G. 1961. Divinity and experience. Oxford: Oxford University Press.

LYNCH, M. \& L.H. RobBINS. 1977. Animal brands and the interpretation of rock art in East Africa. Current Anthropology 18: 538-39.

Marshall, F. 2000. The origins and spread of domestic animals in eastern Africa, in R.M. Blench \& K.C. MacDonald (ed.) The origins and development of African livestock: 191-221. London: UCL Press.

Mire, S. 2008. The discovery of Dhambalin rock art site, Somaliland. African Archaeological Review 25: 153-68.
Muzzolini, A. 2000. Livestock in Saharan rock art, in R.M. Blench \& K.C. MacDonald (ed.) The origins and development of African livestock: 87-110. London: UCL Press.

Nigus, G.M. 2006. New rock art sites in northeastern Ethiopia: their contribution to the development of early food production. Unpublished MA dissertation, Addis Ababa University.

PHILlipson, D.W. 1977. The later prehistory of eastern and southern Africa. London: Heinemann.

Russell, T. 2012. Through the skin: exploring pastoralist marks and their meanings to understand parts of East African rock art. Journal of Social Archaeology 13: 3-30.

Russell, T. \& P. KIURA. 2011. A re-consideration of the rock engravings at the burial site of Namoratung'a South, northern Kenya and their relationship to modern Turkana livestock brands. South African Archaeological Bulletin 66: 121-28.

TORnAY, S. 1973. Langage et perception. La dénomination des couleurs chez les Nyangatom du sud-ouest Éthiopien. L'Homme 14(4): 66-94.

TurTON, D. 1973. The social organisation of the Mursi: a pastoral tribe of the Lower Omo Valley, south west Ethiopia. Unpublished PhD dissertation, University of London.

- 1980. There's no such beast: cattle and colour naming among the Mursi. Man (NS) 15: 320-38.

- 1993. 'We must teach them to be peaceful': Mursi views on being human and being Mursi, in T. Tvedt (ed.) Conflicts in the Horn of Africa: human and ecological consequences of warfare: 164-80. Uppsala: Uppsala University.

- 2004. Lip-plates and 'the people who take photographs': uneasy encounters between Mursi and tourists in southern Ethiopia. Anthropology Today 20(3): 3-8.

Turton, D., M. Yigezu \& O. Olibui. 2008. Mursi-English-Amharic dictionary. Addis Ababa: Culture and Art Society of Ethiopia.

WOODHEAD, L. 1987. A box full of spirits. London: Heinemann.

- 2014. Filmography. Available at: http://www. lesliewoodhead.com/filmography/ (accessed 12 June 2014).

Received: 24 February 2014; Accepted: 24 March 2014; Revised: 8 April 2014 